\title{
Sosiologi Lingkungan Dalam Lontar Taru Pramana: Manusia, Lingkungan, Dan Pengobatan Tradisional Bali
}

\author{
Putu Eka Sura Adnyana \\ Dewan Pimpinan Provinsi Peradah Indonesia Bali \\ email: ekasuraadnyana@gmail.com
}

Diterima tanggal 2 Pebruari 2021, diseleksi tanggal 21 Maret 2021, dan disetujui tanggal 30 Maret 2021

\begin{abstract}
Lontar Taru Pramana is a lontar containing many types of plants that can be used in traditional medicine. Through the contents of Taru Pramana's lontar text, it is possible to trace the types of plants that have lived and are still growing in Bali's natural ecosystem, of course, with an environmental sociology perspective. The relationship between environmental sociology and Taru Pramana's lontar text semiotics explains the meaning of the relationship between humans and the environment. Three conceptions view nature in environmental sociology, namely: 1) Sustainable use of natural resources; 2) "arcadian" approach to the interpretation of nature; 3) natural social construction approach. This conception of nature as a resource has three main characteristics. First, nature is instrumental, which means that nature has value when other values can be manifested through it. Both realms function as a supplier of human material needs, such as food production, health, the availability of space for life, and a supplier of energy and materials. The three definitions of nature are generally closely related to natural science. The preservation of Taru Pramana plants is very important in addition to environmental harmony and as a form of human relations with palemahan (environment). Four types of rationality for human development. First, traditional rationality. The Second, effective rationality. Third, value-oriented rationality. Fourth, instrumental rationality. The ideology of Taru Pramana's text is the preservation and planting of medicinal plants in the ecosystem of traditional Balinese medicine.
\end{abstract}

keywords: environmental sociology; taru pramana; balinese traditional medicine

\begin{abstract}
ABSTRAK
Lontar Taru Pramana merupakan lontar yang memuat banyak jenis tumbuh-tumbuhan yang dapat dimanfaatkan kegunaannya dalam pengobatan tradisional. Melalui isi teks lontar Taru Pramana tersebut, maka dapat ditelusuri jenis tumbuh-tumbuhan yang pernah hidup dan yang masih tumbuh diekosistem alam Bali tentunya dengan perspektif sosiologi lingkungan. Keterkaitan sosiologi lingkungan dengan teks lontar Taru Pramana secara semiotika menjelaskan makna hubungan antar manusia dengan lingkungan. Tiga konsepsi memandang alam dalam sosiologi lingkungan yaitu: 1) Pendekatan pemanfaatan sumber daya alam yang berkelanjutan; 2) pendekatan interpretasi "arcadian" terhadap alam; 3) pendekatan konstruksi sosial alam. Konsepsi alam sebagai sumber daya ini memiliki tiga ciri utama yaitu pertama alam bersifat instrumental yang bermakna alam bernilai manakala melaluinya dapat terwujud nilai-nilai yang lain. Kedua alam berfungsi sebagai pemasok kebutuhan material manusia, seperti produksi pangan, kesehatan, tersedianya ruang untuk kehidupan, dan pemasok energi dan materi. Ketiga definisi alam yang umumnya lekat dengan ilmu pengetahuan alam. Pelestarian tumbuh-tumbuhan Taru Pramana sangat penting untuk keharmonisan lingkungan hidup dan sebagai bentuk hubungan manusia dengan palemahan (lingkungan). Empat tipe rasionalitas perkembangan manusia. Pertama, traditional rationality (rasionalitas tradisional), Kedua, affective rationality (rasionalitas afektif) Ketiga, value oriented rationality (rasionalitas yang berorientasi pada nilai) Keempat, instrumental rationality (rasionalitas insrumental) dalam interaksi terhadap alam dan lingkungan. Ideologi teks Taru Pramana adalah pelestarian dan perencanaan terhadap tumbuh-tumbuhan obat dalam ekosistem lingkungan pengobatan tradisional Bali.
\end{abstract}

kata kunci: sosiologi lingkungan; taru pramana; pengobatan tradisional Bali 


\section{PENDAHULUAN}

Belakangan ini kerusakan lingkungan telah menjadi kondisi yang memprihatinkan. Alam dan ekosistemnya telah tercemar dan tidak seimbang. Tidak hanya itu krisis lingkungan seperti tidak produktifnya tanah untuk ditanami dan semakin langkanya tumbuhan-tumbuhan yang bermanfaat bagi kehidupan manusia. Tentunya ini sebagai akibat eksploitasi lingkungan alam dan alam beserta ekosistemnya pun akhirnya terkorbankan. Bali dan ekosistem lingkungan telah tereksploitasi secara besar-besaran sebagai akibat pariwisata. Jika mengingat sejarah Bali diberikan perhatian khusus oleh pemerintah masa kolonial Belanda, sebagai berikut.

"Let Balinese live their own beautiful native life as undisturbed as possible. Their agriculture, their village-life, their own form of worship, their religious art, their own literature - all bear witness to an autonomous native civilization of rare versatility and richness. No railroad on Bali; no western coffee plantations, and especially no sugar factories. But also no proselytizing, neither Mohammeden (by zealous natives from other parts of Indies), no Protestan, nor Roman Catholic. Let the colonial administration, with the strong backing of the Netherlands (home) government, that the island of Bali as a rare jewel, that we must protect and whose virginity must remain intac", terjemahannya; "Biarkanlah orang Bali meneruskan pola kehidupan pribumi mereka yang indah, bebas dari gangguan apapun. Pertanian mereka, kehidupan pedesaan mereka, aneka bentuk pemujaan, kesenian religius, dan kesusastraan mereka, semuanya itu menunjukkan suatu kebudayaan pribumi yang amat lentur dan kaya. Maka janganlah dibangun jalur kereta api di Bali. Jangan pula membuka perkebunan kopi Barat; dan terutama janganlah membuat pabrik gula. Tetapi jangan juga mengijinkan di Bali suatu kegiatan para misionaris agama, baik yang Islam (pribumi penuh semangat dari daerah-daerah Hindia Belanda lainnya), yang Protestan maupun yang Katolik Roma. Biarkanlah administrasi kolonial, dengan dukungan kuat pemerintah Belanda, memperlakukan Bali sebagai suatu permata langka yang wajib dilindungi dan keperawanannya dijaga utuh" (Picard, 2006: 27).

Terlepas dari adanya politik dan sebagainya, kutipan dari Michael Picard tersebut menjelaskan bahwasanya dulu pada pemerintahan kolonial Belanda, Bali diberikan perhatian khusus baik masyarakat, kebudayaan, lingkungan dan ekosistem alamnya. Namun kini alam Bali telah berubah, banyak tumbuh-tumbuhan yang berkhaziat bagi kehidupan manusia telah langka. Tumbuh-tumbuhan memiliki kontribusi nilai religi dan tumbuh-tumbuhan bernilai sosial budaya Bali yang awalnya mudah didapatkan kondisinya kini semakin langka. Kalaupun masih ada, relatif masih sulit diketahui keberadaannya, kecuali bagi kalangan pembuat sesajen (serati banten) untuk upacara ataupun praktisi-praktisi spiritual religi dan pengobatan. Berdasarkan resiko kepunahannya, kelangkaan tumbuh-tumbuhan dapat dikategorikan menjadi extinct (punah), extint in the wild (punah di alam), critically endangered (sangat langka/kritis), endangered (langka/genting), vulnerable (rawan), lower risk (resiko rendah/ terkikis), data deficient (data tidak memadai) dan not evaluated (belum dievaluasi) (IUCN, 1998; Irawati, dkk., 1994). 
Salah satu lontar yang dapat menjadi rujukan berkaitan tumbuh-tumbuhan yang berkhaziat dan memiliki fungsi pengobatan bagi masyarakat adalah lontar Taru Pramana. Lontar Taru Pramana merupakan lontar yang memuat banyak jenis tumbuh-tumbuhan yang dapat dimanfaatkan kegunaannya dalam pengobatan tradisional. Taru Pramana berasal dari kata taru memiliki arti pohon, kayu atau tumbuhan, dan kata Pramana memiliki arti kekuasaan, kedaulatan (Mardiwarsito, 1985:264). Dapat diartikan Taru Pramana adalah suatu tulisan jenis tumbuh-tumbuhan yang memiliki khaziat kekuatan dan fungsi sebagai obat untuk manusia. Melalui isi teks lontar Taru Pramana tersebut, maka dapat ditelusuri jenis tumbuh-tumbuhan yang pernah hidup dan yang masih tumbuh diekosistem alam Bali tentunya dengan perspektif sosiologi lingkungan. Keterkaitan sosiologi lingkungan dengan teks lontar Taru Pramana secara semiotika menjelaskan makna hubungan antar manusia dengan lingkungan. Tulisan ini bertujuan untuk menjelaskan isi teks lontar Taru Pramana dalam ranah kacamata sosiologi lingkungan dalam bentuk hubungan timbal balik manusia dengan lingkungan; manusia sebagai penjaga dan pejuang lingkungan serta perancang keberlanjutan lingkungan. Tentunya dengan tujuan tersebut bermanfaat untuk membedah dan menjelaskan amanat yang terkandung dalam isi teks lontar Taru Pramana untuk menjaga lingkungan terutamanya tumbuh-tumbuhan yang memiliki khaziat pengobatan.

\section{PEMBAHASAN}

\subsection{Sosiologi Lingkungan dalam Lontar Taru Pramana}

Sosiologi Lingkungan atau environment sociology didefenisikan sebagai cabang sosiologi yang memusatkan kajiannya pada adanya keterkaitan antara lingkungan dan perilaku sosial manusia. Van Koppen (dalam Sumarti, 2007) menjelaskan tiga konsepsi memandang alam dalam sosiologi lingkungan yaitu: 1) Pendekatan pemanfaatan sumber daya alam yang berkelanjutan; 2) pendekatan interpretasi "arcadian" terhadap alam; 3) pendekatan konstruksi sosial alam. Konsepsi alam sebagai sumber daya ini memiliki tiga ciri utama yaitu pertama alam bersifat instrumental yang bermakna alam bernilai manakala melaluinya dapat terwujud nilai-nilai yang lain. Kedua alam berfungsi sebagai pemasok kebutuhan material manusia, seperti produksi pangan, kesehatan, tersedianya ruang untuk kehidupan, dan pemasok energi dan materi. Ketiga definisi alam yang umumnya lekat dengan ilmu pengetahuan alam. Menurut Dunlap dan Catton (dalam Susilo, 2012:6-7) sosiologi lingkungan dibangun dari beberapa konsep yang saling berkaitan, yaitu: 
1. Persoalan-persoalan lingkungan dan ketidakmampuan sosiologi konvensional untuk membicarakan persoalan-persoalan tersebut merupakan cabang dari pandangan dunia yang gagal menjawab dasar-dasar biofisik struktur sosial dan kehidupan sosial.

2. Masyarakat modern tidak berkelanjutan (unsustainable) karena mereka hidup pada sumberdaya yang sangat terbatas dan penggunaan di atas pelayanan ekosistem jauh lebih cepat jika dibandingkan kemampuan ekosistem memperbaharui dirinya. Dan dalam tataran global, proses ini diperparah lagi dengan pertumbuhan populasi yang pesat.

3. Masyarakat menuju tingkatan lebih besar atau lebih kurang berhadapan dengan kondisi yang rentan ekologis.

4. Ilmu lingkungan modern telah mendokumentasikan kepelikan persoalan lingkungan tersebut dan menimbulkan kebutuhan akan penyelesaian besar-besaran jika krisis lingkungan ingin dihindari.

5. Pengenalan dimensi-dimensi krisis lingkungan yang menyumbang pada 'pergeseran paradigma' dalam masyarakat secara umum, seperti yang terjadi dalam sosiologi berupa penolakan terhadap pandangan dunia Barat yang dominan dan penerimaan sebuah paradigma ekologi baru.

6. Perbaikan dan reformasi lingkungan akan dilahirkan melalui perluasan paradigma ekologi baru di antara publik, massa dan akan dipercepat oleh pergeseran paradigma yang dapat dibandingkan antara ilmuan sosial dan ilmuan alam.

Koppen (dalam Sumarti, 2007) menjelaskan lebih lanjut jika sosiologi lingkungan yang berakar dengan pendekatan Arcadian, melahirkan empat tradisi penting yang berkaitan dengan budaya, diantaranya:

1. Tradisi simpati pada binatang. Pengalaman emosional bersahabat dengan binatangbinatang yang lebih tinggi. Misalnya termanifestasikan dengan ketidaksukaan terhadap kekerasan pada binatang. Proses peradaban tidak hanya mengintensifkan sensibilitas kita terhadap kekejaman pada manusia maupun binatang. Hukum tentang kekerasan terhadap binatang mungkin pelembagaan hukum modern pertama dari nilai-nilai alam yang non instrumental.

2. Tradisi menikmati keindahan dan kecantikan alam dan landscape. Gambaran terhadap kegembiraan musim seni, kecantikan bunga, kelucuan binatang sama tuannya dengan seni dan literature itu sendiri. Penilaian terhadap keindahan landscape pedesaan.

3. Tradisi sejarah alam. Pengembangan sejarah alam dalam ilmu seperti botani, zoologi, dan geografi terkait erat dengan tradisi estetika. 
4. Tradisi keagamaan tentang hidup dan rahasia alam raya. Tradisi keagamaan tentang nilai alam termanifestasikan dalam sejarah barat. Pengaruh supernaturalisme alam dapat diikuti pada seni modern barat.

Pendekatan Arcadian memberikan tempat pada nilai-nilai intrinsik alam seperti dimensi emosional, moral, estetika, dan ilmiah. Alam seperti dinilai oleh pendekatan Arcadian. Berbeda secara khas dengan lingkungan yang berarti tempat hidup dan landscape. Dengan kata lain alam benar-benar hijau. sosiologi lingkungan menjelaskan alam sebagai sesuatu secara simbolik daripada yang ada secara objektif. Sosiologi lingkungan dengan menekankan peranan budaya dan simbolnya dalam mengkonseptualkan tentang alam. Dukungan teoritis untuk membangun konsep alam non sumber daya melalui dua jalur: (1) elaborasi tradisi kultur barat dan tradisi kultur non-barat; (2) mendemonstrasikan kontingensi konsep alam secara utilitarian, teknologi, dan modern melalui konteks sosial dan budayanya dengan kata lain melalui analisa kontruksi sosialnya.

Lontar Taru Pramana merupakan bagian dari produk sosiologi lingkungan dengan menekankan pada budaya pengobatan tradisional Bali. Pendekatan Arcadian sebagaimana dalam lontar Taru Pramana merupakan bentukan kesusastraan pengembangan ilmu botani yang berkaitan erat dengan tradisi estetika yang disampaikan oleh pangawi dalam teks tersebut. Kontruksi nama tumbuh-tumbuhan dalam lontar Taru Pramana merupakan suatu hal penting bagi ilmu sosiologi lingkungan, oleh karena alam dan lingkungan merupakan suatu kontruksi sosial serta merupakan produk dari kegiatan yang teroganisasi secara sosial, sebagaimana fungsi teks Lontar Taru Pramana untuk pengobatan tradisional masyarakat pada masa dulu. Berikut nama tumbuh-tumbuhan yang terkontruksi sosial antara seorang pendeta yang bernama Mpu Kuturan dengan tumbuh-tumbuhan berkhaziat, diantaranya;

Taru Bingin atau pohon beringin (nama ilmiah: ficus benjamina), Kaselaguwi atau sidaguri/ seleguri (nama ilmiah: sidarhombhifolia I), Taru Dadap atau pohon dadap (nama ilmiah: erythrina sumbumbrans), Taru Kelor atau pohon kelor (nama ilmiah: moringa oleifera juss), Taru Bila atau Pohon Bila (nama ilmiah: aegle marmelos) Taru Kalenco atau Pohon Kalence (nama ilmiah: diospyros malabarica), Taru Kepah atau Pohon Kepah (Stercukea foetida L), Taru Beilmiahg Gada atau kaktus (nama ilmiah: cereus peruviabus), Taru Pakel atau pohon pakel (nama ilmiah: mangifer sp), Taru Sumaga atau pohon jeruk (nama ilmiah: citrus nolibis), Taru Kepundung atau kepundung (nama ilmiah: baccauread dulcis), Poh Weni atau pohon weni (nama ilmiah: magifera sp), Taru Cenangga atau Pohon Mangga (nama ilmiah: milingtonia hortensis), Taru Suren atau Pohon Suren (nama ilmiah: toona sureni merr), Taru Sentul atau Pohon Kecapi (nama ilmiah: sandoricum koetjape merr), Taru Sotong atau pohon jambu biji 
(nama ilmiah: psidium guajava L); Taru Gatep atau pohon gayam (nama ilmiah: inocarpus fagiferus); Taru Pule atau pohon pule (nama ilmiah alxian reinwardtii) Taru Cemara atau Pohon Cemara (nama ilmiah: casuria equisetifolia); Taru Kliki atau pohon jarak kepyar (nama ilmiah: Jayatropha curcus L), Taru Nangka atau pohon nangka (nama ilmiah: Annona murricata L), Taru Awar-awar atau pohon awar-awar (nama ilmiah: ficus septica); Taru Wit Jeruju atau pohon daruju (nama ilmiah: acanthus ebracatus); Taru Belimbing atau pohon belimbing (nama ilmiah: averrhoa); Taru Delima atau pohon delima (nama ilmiah: Punia granatum L); Taru Tangi atau pohon bangur (nama ilmiah: lagerstroemiaspeciosa); Taru Buyung-buyung atau pohon buyungbuyung (nama ilmiah: vernonia cineria less); Tabya Dakep atau cabe puyang (nama ilmiah: piper retrpfractum); Taru kepel atau pohon kepel (nama ilmiah: manglietia glauca); Taru belimbing manis atau blimbing manis (nama ilmiah: averrhooa bilimbi); Belimbing besi atau blimbing basi (nama ilmiah: averrhoa carambola); Kasimbukan atau Kasimbukan (nama ilmiah: paederia foetida L); Taru Dangolo atau pohon gandolo, gondola (nama ilmiah: bassella rubra L); Taru Pepe atau Pohon Kpepe (nama ilmiah: sarcostemma esculentum);

Paya atau Pohon Pare (nama ilmiah: momurdica charantia); Tuwung atau Terong, jeruk sitrun (nama ilmiah: citrus aurantifolia); Uyah-uyahan atau uyah-uyah (nama ilmiah: ficus quercifolia); Taru Manggi atau semanggi (nama ilmiah: marselia crenata); Parcarsona atau pancarsona (nama ilmiah: tinospora coriaceae); Juwet atau pohon juwet, sekui,duwet (nama ilmiah: eugenic cumini druse); Nyuh gading atau kelapa gading (nama ilmiah: cocos nucifera L); Taru Cremen atau Pohon Ceremai (nama ilmiah: phyllanthus acidus); Manas atau Nanas (nama ilmiah: annanas sp); Wit Sempol atau Iwit Sempol (nama ilmiah: hedychium ceronarium); Myanacemeng atau miana cemeng (nama ilmiah: coleus scutellarrioides);Taru ancak atau ancak (nama ilmiah: ficus religiosa); Taru wani atau kemang (nama ilmiah: mangifera caesia jack); Kakara manis atau kacang kara (nama ilmiah: phaseolus oleracea L); Poh gedang atau mangga kestri (nama ilmiah: mangifera indica); Katimun Gantung atau ketimun gantung (nama ilmiah: cucumis sativus); Keladi atau talas (nama ilmiah: colocasia plumbea); Liligundi atau legundi (nama ilmiah: vitex trifolia L); Base atau Sirih (nama ilmiah: piper betle L); Damuh-damuh atau damuh-damuh (nama ilmiah: merrenia emarginata HALL); Taru Terong atau terung (nama ilmiah: citrus aurantifolia); Taru majagawu atau pohon gaharu (nama ilmiah: aquilaria sp); Taru limo atau jeruk limo (nama ilmiah: citrus amblicarpa); Taru kecubung atau kecubung (nama ilmiah: datura metel L); Sekapa atau gadung (nama ilmiah: Diosscorea hispida L); Taru pangi atau keluak (nama ilmiah: pangium edule); Ikuh lutung putih atau ikut lutung putih (nama ilmiah: acalipha hispida); Legundi kebo atau legundi (nama ilmiah vitex trifolia L); Taru sembung atau 
sembung (nama ilmiah: blumea balsanifera dc); Taru tingkih atau kemiri (nama ilmiah: aleurites molluccana willd); Taru panyisih atau peyisih (nama ilmiah: phyllanthuis buxifolius);

Taru Pahang atau Pahang (nama ilmiah: acasia robusta wild);Taru cenana atau kayu cendana (nama ilmiah: santalium almbum L); Taru sembung tulang atau kayu patah tulang (nama ilmiah: euphorbia turivalling L); Taru Jali atau jail (nama ilmiah: coix lacryma-jobi L); Taru Kroya atau pohon kroya (nama ilmiah: ficus infectoria); Taru uwut-uwut atau kayu uwutuwut (nama ilmiah: aleurite moluccana); Taru tingulun atau kayu tingulun (nama ilmiah: protium javanicum); Taru tehep atau bendo (nama ilmiah: artacarpus); Taru piling atau saga (nama ilmiah: abrus precatoris L); Taru bunut bulu atau bunut bulu (nama ilmiah: ficus annulate); Taru kaleyan atau kalian (nama ilmiah: bleghia sp); Crangcang kawat atau pohon asparagus (nama ilmiah: asparagus sp); Taru poh heni atau manga heni (nama ilmiah: mangifera sp); Taru bawang-bawang atau pohon bawang (nama ilmiah: premna obtusifolia); Taru pucuk atau kembang sepati (nama ilmiah hibiscus rosasinensis); Taru kepahai atau pohon kepah (nama ilmiah: stercukea foetida L); Taru basa-basa atau pohon basa-basa (nama ilmiah: clausena sp); Taru uduh atau pohon uduh (nama ilmiah: pinanga coronata); Taru gedang atau papaya (nama ilmiah: carica papaya);Taru pancarsona atau pancarsona (nama ilmiah: tinospora coriaceae); Taru galing-galing atau galing-galing (nama ilmiah: cayratia trifolia); Taru dagadagse atau kolbanda (nama ilmiah: pisonia alba span); Taru lambon kutuh atau ketela pohon putih (nama ilmiah: manihot uttilisima); Taru krasi atau pohon lantana (nama ilmiah: lantana camara); Taru kenari atau pohon kenari (nama ilmiah: canarium vulgare); Taru bawang-bawang brahma (nama ilmiah: allium cepa);

Taru keladi gowak atau pohon talas hitam (nama ilmiah: alocasia plumbea); Taru manggis atau pohon manggis (nama ilmiah: garcinia mangostana I); Taru cempaka kuning atau pohon cempaka kuning (nama ilmiah: millingtonia hortensis); Taru Kalimoba atau kayu ombo (nama ilmiah: ficus binendiskii); Taru Jempiring atau kaca piring (nama ilmiah: gardenia florida L); Taru palitsedangan atau palit sedang (nama ilmiah: thevea peruviana K.Schum); Gadung kasturi atau gadung kasturi (nama ilmiah: dioscorea pentaphylla); Taru awar-awar atau awarawar (nama ilmiah: ficus septica); Bun mica atau tanaman merambat merica (nama ilmiah: piper ningrum); Gamongan atau lempuyang (nama ilmiah: zingibera zerumbet); Kliki atau jarak kepyar (nama ilmiah: jatropha curcus L); Taru manis atau katu (nama ilmiah: sauropus androginus); Taru kadongdong atau kedongdong (nama ilmiah: spondiac dulcis); Taru inganingan atau ingan-ingan (nama ilmiah: flemingia congesta roxb); Taru tigaron atau tigaron (nama ilmiah: crataeca nurvala buch ham); Taru pengeng-pengeng (nama ilmiah: pedilanthus tithymaloides); Teleng atau teleng (nama ilmiah: Clitoria ternatea L); Taru tamplas atau amplas 
(nama ilmiah: ficus ampelas burm F); Kasa-kasa atau kapulaga (nama ilmiah: anomum maximum roxb); Kamurugan atau kamurugan (nama ilmiah: gymnospetalum sp); Bun paperon atau ki kuning (nama ilmiah: arccangelisia); Jarak atau jarak pagar (nama ilmiah: ricinus communis L); Blego atau bligo (nama ilmiah: berincasa hispida cogn); Kangkang yuyu atau kangkang yuyu (nama ilmiah: cyclea barbata); Paku jukut atau pakis sayur (nama ilmiah: athyrium esculentum); Kapas atau kapas (nama ilmiah: gossypium barbecius);

Kepasilan juuk atau benalu jeruk (nama ilmiah: viscum articulatum); Samblung atau samlung (nama ilmiah: epipremnum pinatum ENGL); Taru Belimbing basi atau belimbing basi (nama ilmiah: averrhoa bilimbi); Taru kutuh atau kapuk randu (nama ilmiah: ceiba petandra); Taru kelasih atau telasih (nama ilmiah: ocimum bacilicum l); Taru kenari atau kenari (nama ilmiah: canarium vulgare); Taru kenarak atau rerak (nama ilmiah: sapindus rarak Dc); Taru poh amplem atau mangga amplem (nama ilmiah: magifera sp); Tiing Ampel Gading atau bambu ampel gading (nama ilmiah: bambosavulgaris); Tiih atau suwek duri (nama ilmiah: amorphopalus sp); Taru awar-awar Brahma atau awar-awar merah (nama ilmiah: ficus septica); Ketimun uku atau mentimun rambat (nama ilmiah: cucumis sativus); Tebu malem atau tebu hitam (nama ilmiah: saccharum officinarum); Taru paku lelipi atau paku (nama ilmiah: crassula sp); Kasegseg atau kasegsegan (nama ilmiah: purtulaca oleracea L) (Sukersa, 2017).

\subsection{Hubungan Manusia dengan Palemahan Dalam Lontar Taru Pramana}

Tumbuhan adalah gudang bahan obat yang memiliki banyak manfaat untuk obat berbagai penyakit. Kemampuan meracik tumbuhan berkhasiat obat dan jamu merupakan warisan turun temurun dan mengakar kuat di masyarakat. Tumbuhan yang merupakan bahan baku obat tradisonal tersebut tersebar hampir di seluruh wilayah Indonesia, terutamanya Bali.Tumbuhtumbuhan itu telah dimanfaatkan oleh manusia dalam kehidupan, sejak awal peradaban seperti untuk sandang, pangan, dan papan. Hubungan manusia dengan lingkungan (palemahan) di Bali menyatu dan menjadi bagian satu kesatuan. Kesatuan itu sangat terlihat ada teks Taru Pramana, karena sastra (lontar) lahir dari realitas sosial, maka sastra (lontar) menggambarkan keadaan sosial. Keadaan sosial yang tergambarkan bisa dipahami dalam kutipan teks taru pramana berikut ini.

Iki kaputusan taru pramana, duking hatika hana anama sang prabhu mpu kuturan, amalakun dudukan sira, kuang pira lamin ira, siddha siddhi pwa sira angusadaning, hana pwa masadya mandya bagia, sahananin wang tinamban, de sang prabhu, hana sata hanania, pejah sadaya wetu mageleng ri anggania dewek, las tantunaken dwa, hana inihasa de ya asraya ring setra ulu ring pamuwun, wus agenep salek sapta dina, tumurun, batara ring kahyangan, asung hira warah-warah, lamakane sira weruh ing angaraning taru, yan atanya ing ya, apa parania muang gunania sowang-sowang, wus mangkana sang prabhu mpu kuturan teher angarada taru lata, 
trena gulmapratamia dating, ika pwa wreksa wandira raris umatur, inggih ratu sang prabhu punapi mawinan I ratu maswambawa kadi pamanggeh tur mangesengin kadi titiang. Mangkin ngandika sang prabhu. ih nyen ne iba bingin, wireh awake dadi balian tan sida nyegerang jani makeneh nyekenang nakonang I kayu diri-diri. Apa gunnyane, kenken daging nyane, muang dadi ubad apa, mangkana ujara sang prabhu mpu kuturan. Dadia I taru bingin mapamit wus punika sang prabhu mpu kuturan malih ngarad tan dumada raris rawuh witing:

Terjemahannya:

Inilah yang disebutkan dalam taru pramana, ketika ada seorang raja bernama Mpu Kuturan, menjalankan pekerjaan sebagai dukun, beberapa lama kemudian, amat berhasillah beliau mengobatin, sangat berbahagialah beliau, semua yang diobati oleh sang raja menjadi sembuh, ada seratus banyaknya semua mati sangat sedihlah beliau dalam dirinya, tidak bisa ditolongnya, lalu beliau bersemedia ditengah-tengah kuburan (pamuwun), setelah mencapai tujuh hari lamanya, turunlah dewa dari khayangan, memberikan nasihat, supaya beliau tahu tentang nama-nama tumbuh-tumbuhan, jika bertanya kepadanya, apa yang menjadi tujuannya dan kegunaannya masing-masing, setelah selesai kemudian raja Mpu Kuturan memanggil kepada tumbuhtumbuhan melata, rumput yang menjalar semua dating, seperti pohon bringin kemudian bertanya, Oh sang raja apa yang menyebabkan memanggil saya ini. Kemudian menjawablah sang raja, oh siapa kamu ini pohon beringin, saya menjadi dukun tidak dapat menyembuhkan penyakit oleh karena itu saya menanyakan tumbuhan masing-masing, apa kegunaannya, bagaimana isinya dan dapat mengobati penyakit apa. Demikian ucapan sang raja Mpu Kuturan kemudian pohon beringin pergi, lalu sang raja memanggil tumbuhan yang lain..." (Jumadiah, 2009)

Berdasarkan kutipan mitologi tumbuh-tumbuhan yang dapat berbicara dalam lontar Taru Pramana berkat anugrah dewa dari kahyangan kepada seorang raja yang bernama Mpu Kuturan sehingga dapat berkomunikasi kepada semua tumbuh-tumbuhan tentang tujuan dan manfaatnya dalam pengobatan segala macam penyakit. Ini memberikan amanat kepada manusia bahwa semua mahluk hidup di dunia ini termasuk tumbuh-tumbuhan bermanfaat untuk kehidupan. Karena itu pelestarian tumbuh-tumbuhan Taru Pramana sangat penting untuk keharmonisan lingkungan hidup dan sebagai bentuk hubungan manusia dengan palemahan (lingkungan).

Adnyana (2019) menjelaskan kasuna (bawang putih) berfungsi untuk membantu dan mengobati beberapa penyakit, seperti: (1) Penyakit Beteg (beri-beri) dapat digunakan dengan bahan seperti: Daun, akar, getah kulit dan Kasuna jangu, mayeh cuka. Kemudian dapat diolah dengan cara dihaluskan, disaring, diminum atau bisa juga menggunakan bahan lain seperti kulit pada pohon Bila, Kasuna jangu, yeh cuka (air cuka) dapat diolah dan digunakan sebagai boreh. (2) Penyakit Puruh (vertigo) dapat diobati dengan bahan-bahan seperi daun pengeng-pengeng dan kasuna jangu, Pengolahannya dengan cara diulig (diratakan dengan halus), kemudian semua bahan lalu tempelkan pada dahi. (3) Penyakit Rangsek (sesak nafas) dapat diobati dengan bahanbahan seperti Daun Kuanta, Kasuna jangu, temu tis kemudian diolah dengan cara dikunyah halus lalu semburkan pada dada yang sakit. (4) Penyakit batuk dapat diobati dengan Daun Bunut Bulu, Kasuna jangu, kemudian pengolahannya dapat dikunyah halus lalu semburkan di dada.

Kebiasaan masyarakat dalam menggunakan obat-obatan alami dilakukan secara turun temurun. Tanaman obat yang biasa digunakan oleh masyarakat untuk mengobati berbagai 
penyakit dibudidayakan atau ditanam sebagai tanaman obat keluarga oleh masyarakat. Hal tersebut merupakan salah satu upaya untuk melestarikan keanekaragaman tanaman yang berpotensi sebagai obat-obatan. Pengetahuan tentang pemanfaatan tanaman obat merupakan warisan budaya bangsa terutamanya masyarakat Bali berdasarkan pengalaman, pengetahuan, dan keterampilan, yang secara turun-temurun telah diwariskan oleh leluhur melalui teks lontar Taru Pramana.

\subsection{Manusia sebagai Penjaga dan Perancang Keberlanjutan Lingkungan}

Tanaman obat sebagai laboratorium botani sangat diperlukan. Peranan laboratorium botani sebagai media pendidikan dan penelitian perlu mendapat perhatian khusus dari pemerintah daerah, mengingat masih banyak keanekaragaman hayati yang belum dikaji secara lebih mendalam untuk memberikan manfaat yang besar bagi kesejahteraan hidup. Manusia wajib menjaga pelestarian tumbuh-tumbuhan yang bermanfaat bagi kehidupannya terutamanya pada teks Taru Pramana. Tujuan pelestarian tumbuh-tumbuhan, sebagai bahan obat adalah sebagai berikut (1) menjaga keseimbangan ekosistem agar kehidupan dimuka bumi ini tetap berjalan dengan baik. (2) melestarikan keanekaragaman hayati yang bermanfaat bagi ilmu pengetahuan dan masyarakat. (3) menciptakan lingkungan yang nyaman dan mengurangi pencemaran udara dengan tumbuhnya berbagai pohon. (4) dapat dimanfaatkan sebagai taman rekreasi (Adnyana, 2019).

Manusia wajib sebagai perancang keberlanjutan lingkungan yang bermanfaat bagi kehidupannya. Merujuk lontar Taru Pramana “...Titiang wit dapdap tis wawu rawuh, babakan titiange dados anggen tamba bengka, rawuhing katumbah bolong 11 besik, uyah areng pinipis, pres saring , tahapakna...”.“... Saya ini adalah akar dari pohon dapdap yang dapat menyejukkan, kulit saya dapat dipakai obat perut kembung, dicampur dengan ketumbar 11 biji dicampur dengan garam dilumatkan kemudian diperas airnya dijadikan jamu lalu diminum..." “...Titiang wit kelor daging tis engket barak nyem, akah panes, dawun titiange dados anggen tamba sakit mata, rawuhing jeruk lengis , uyah areng saring degdegang, tutuh netrania...”.“... Saya adalah pohon kelor, kulit saya sejuk (tis), getahnya merah yang juga dingin, akar saya panas, daun saya dapat dipakai obat sakit mata dicampur dengan jeruk nipis, dan garam kemudian dilumatkan dan ditambah air, kemudian didiamkan lalu disaring, kemudian dipakai untuk mengobati mata..."

Berdasarkan teks di atas, sungguh besar manfaat tumbuh-tumbuhan sebagai obat untuk kesehatan manusia yang tidak menimbulkan efek samping, oleh karena itu keberadaan lontar Taru Pramana perlu disebarluaskan dalam masyarakat sehingga keberadaan tumbuh-tumbuhan 
perlu dilestarikan dengan cara menanam tumbuh-tumbuhan itu minimal dalam pekarangan dalam rumah tangga. Dengan demikian akan dapat melestarikan lingkungan hidup. Ada 168 nama tumbuhan Bali yang ada dalam Usada Taru Pramana (Jumadiah, 2009:ii). Pengetahuanpengetahuan tersebut tersusun secara sistematis oleh pangawi dalam teks tersebut merupakan ilmu pengetahuan dalam penggunaan tumbuh-tumbuhan dalam pengobatan tradisional Bali.

Sejalan dengan peraturan pemerintah Indonesia dalam Undang-Undang Nomor 4 Tahun 1982 tentang Ketentuan- Ketentuan Pokok Pengelolaan Lingkungan Hidup. 2. Surat Keputusan Menteri Perindustrian Nomor 148/11/SK/4/1985 tentang Pengamanan Bahan Beracun dan Berbahaya di Perusahaan Industri. 3. Peraturan Pemerintah (PP) Indonesia Nomor 29 Tahun 1986 tentang Analisis Mengenai Dampak Lingkungan Hidup. 4. Pembentukan Badan Pengendalian Lingkungan Hidup pada tahun 1991. Berdasarkan peraturan pemerintah tersebut dapat dipahami bahwa manusia disiapkan sebagai perancang dan perencanaan keberlanjutan dari pelestarian lingkungan. Bentuk rasionalitas manusia meliputi mean (alat) yang menjadi sasaran utama serta ends (tujuan), yang meliputi aspek kultural (Martono, 2012). Empat tipe rasionalitas perkembangan manusia. Pertama, traditional rationality (rasionalitas tradisional), yaitu rasionalitas yang bertujuan untuk memperjuangkan nilai yang berasal dari tradisi kehidupan manusia. Zaman dulu, nenek moyang kita menggunakan mitos, cerita dongeng atau cerita rakyat sebagaimana teks lontar Taru Pramana untuk memelihara alam dan lingkungan. Menjaga kerusakan lingkungan yang dilakukan dengan memberikan mitos, dan ajaran yang dipegang kuat oleh generasi pada masa itu yang diturunkan melalui cakepan lontar Taru Pramana.

Kedua, affective rationality (rasionalitas afektif) merupakan tipe rasionalitas yang bermuara dalam hubungan emosi atau perasaan (mendalam). Ketika manusia masih berpikir secara tradisional, maka mitos atau ajaran yang diberikan akan dituruti dengan baik oleh seluruh manusia pada zaman itu. Rasionalitas itu hendaknya mampu melihat dan memahami warisan leluhur melalui teks Taru Pramana bahwa tumbuh-tumbuhan itu sangat bermanfaat bagi kehidupan dan memiliki nilai ekonomis jika mampu ditransformasikan pada ranah yang modern. Ketiga, value oriented rationality (rasionalitas yang berorientasi pada nilai) merupakan suatu rasionalitas masyarakat yang melihat nilai sebagai potensi atau tujuan hidup. Value atau nilai dianggap penting bagi masyarakat secara menyeluruh. Ketika ajaran Taru Pramana mampu dipahami, dengan perancangan tumbuh-tumbuhan dengan keilmuan modern masa kini demi keberlangsungan lingkungan hidup maka akan memunculkan nilai ekonomi, nilai kesejahteraan, dan nilai akan kemajuan suatu peradaban manusia. Keempat, instrumental rationality (rasionalitas insrumental) atau sering juga disebut dengan tindakan dan alat. Manusia tidak hanya menentukan tujuan yang ingin dicapai. Namun, ia secara rasional telah 
mampu menentukan alat (instrumental) yang akan digunakan untuk mencapai tujuan tersebut. Rasionalitas ini menekankan pada pencapaian tujuan manusia dengan alat atau instrumen untuk mencapai tujuan manusia. Rasionalitas manusia mempengaruhi keberadaan generasi di masa mendatang, apakah regeneratif dalam keberlanjutan alam dan lingkungan diperhatikan atau tidak sama sekali.

\subsection{Ideologi Teks Taru Pramana}

Alam dan lingkungan tidak hanya sebagai tempat manusia untuk hidup. Setelah ditaklukan dan memperjuangkan lingkungan, ada satu tindakan yang mesti dilakukan manusia. Merencanakan dan merancang keberlanjutan lingkungan dan alam. Teks Taru Pramana menyiratkan ideologi yang patut dipahami oleh manusia, karena ideologi merupakan cara pandang membentuk karakter berpikir dalam mewujudkan keinginan atau cita-cita. Menurut Kamus Besar Bahasa Indonesia (2015) ideologi merupakan kumpulan konsep bersistem yang dijadikan asas pendapat (kejadian) yang memberikan arah dan tujuan untuk kelangsungan hidup. Ideologi teks Taru Pramana adalah pelestarian dan perencanaan terhadap tumbuh-tumbuhan obat dalam ekosistem lingkungan pengobatan tradisional Bali. Itu dimaksudkan agar generasi selanjutnya bisa memanfaatkan alam sebagai kebutuhan generasi di masa mereka. Karena pentingnya keberlanjutan lingkungan terhadap kehidupan masa depan setiap generasi.

Muncul kesadaran akan pentingnya merencanakan dan merancang keberlanjutan lingkungan untuk masa sekarang dan mendatang. Manusia mulai untuk tidak mengeksploitasi alam secara liar dan besar-besaran. Bruce Mitchell menyatakan krisis lingkungan dewasa ini tidak lepas dari pandangan sistem reduktif (menjadi sederhana) yang sekaligus menjadi watak ilmu pengetahuan modern. Watak seperti ini sepintas bisa merupakan kelebihan ilmu pengetahuan, tetapi juga sekaligus kelemahan (Susilo, 2012). Sebagaimana yang dinyatakan Bruce Mitchel, sama halnya dengan kelangkaan tumbuh-tumbuhan yang disebutkan dalam lontar Taru Pramana menyebabkan mulai krisisnya pengetahuan pengobatan tradisional Bali (usadha) pada generasi selanjutnya. Kearifan lokal tradisional seperti contoh pada Taru Pramana tidak lagi digunakan pada era sekarang. Oleh karena itu, dalam merencanakan sebuah keberlanjutan alam dan lingkungan, ada baiknya kita juga memperhatikan kearifan masyarakat.

Rasionalitas tradisional mungkin masih relevan digunakan dalam proses merencanakan dan merancang keberlanjutan lingkungan untuk kehidupan generasi mendatang. Cara-cara yang sudah diwariskan bisa digali dan diterapkan pada proses penghormatan kepada alam dan lingkungan. Berpikir secara rasional dengan mengedepankan aspek lingkungan dan alam serta masyarakat untuk membuat sebuah konsep keberlanjutan lingkungan. 


\section{PENUTUP}

Melalui isi teks lontar Taru Pramana, maka dapat ditelusuri jenis tumbuh-tumbuhan yang pernah hidup dan yang masih tumbuh diekosistem alam Bali tentunya dengan perspektif sosiologi lingkungan. Keterkaitan sosiologi lingkungan dengan teks lontar Taru Pramana secara semiotika menjelaskan makna hubungan antar manusia dengan lingkungan. Tiga konsepsi memandang alam dalam sosiologi lingkungan yaitu: 1) Pendekatan pemanfaatan sumber daya alam yang berkelanjutan; 2) pendekatan interpretasi "arcadian" terhadap alam; 3) pendekatan konstruksi sosial alam. Konsepsi alam sebagai sumber daya ini memiliki tiga ciri utama yaitu pertama alam bersifat instrumental yang bermakna alam bernilai manakala melaluinya dapat terwujud nilai-nilai yang lain. Kedua alam berfungsi sebagai pemasok kebutuhan material manusia, seperti produksi pangan, kesehatan, tersedianya ruang untuk kehidupan, dan pemasok energi dan materi. Ketiga definisi alam yang umumnya lekat dengan ilmu pengetahuan alam.

Pelestarian tumbuh-tumbuhan Taru Pramana sangat penting untuk keharmonisan lingkungan hidup dan sebagai bentuk hubungan manusia dengan palemahan (lingkungan). Empat tipe rasionalitas perkembangan manusia. Pertama, traditional rationality (rasionalitas tradisional), Kedua, affective rationality (rasionalitas afektif) Ketiga, value oriented rationality (rasionalitas yang berorientasi pada nilai) Keempat, instrumental rationality (rasionalitas insrumental). Ideologi teks Taru Pramana adalah pelestarian dan perencanaan terhadap tumbuh-tumbuhan obat dalam ekosistem lingkungan pengobatan tradisional Bali.

\section{DAFTAR PUSTAKA}

Adnyana, Putu Eka Sura. 2019. "Lontar Taru Pramana: Pelestarian Budaya Pengobatan Tradisional Bali” Dalam Jurnal Yoga Kesehatan Vol .2 No. 2 Tahun 2019. Denpasar: Jurusan Yoga Dan Kesehatan Fakultas Brahma Widya Institut Hindu Dharma Negeri Denpasar

Irawati, D. dkk. 1994. "Evaluasi Status Kelangkaan Beberapa Jenis Tumbuhan Langka dari Maluku dan Sulawesi”. Makalah disajikan dalam Seminar Diskusi Sehari mengenai Biodiversity di Indonesia Dirjen PHPA Departemen Kehutanan. Jakarta.

IUCN. 1998. IUCN Red List Catagories (versi Bahasa Indonesia). Penyunting Didik Widyatmoko.

Jumadiah, Sri. 2009. Usada Taru Pramana. Denpasar: Yayasan Dharma Pura.

Mardiwarsito, L. 1985. Kamus Jawa Kuna-Indonesia. Ende-Flores: Nusa Indah.

Martono, Nanang. 2012. Sosiologi perubahan sosial. Jakarta: Raja Grafindo Persada. 
Pichard, Michel. 2006. Bali: Pariwisata Budaya dan Budaya Pariwisata. Jakarta: Perpustakaan Populer Gramedia.

Sukersa, I Wayan. 2017. Usada Taru Pramana: Sebuah Wahana Pelestarian Flora Bahan Obat Tradisional Bali dalam Buku Prabhajnana Kajian Pustaka Lontar Universitas Udayana (hal 1-26). Denpasar: Swasta Anulus.

Sumarti, Titik. 2007. Sosiologi Lingkungan dalam buku Ekologi Manusia. Bogor: Fakultas Ekologi Manuia Institut Pertanian Bogor

Susilo, Rachmad K. Dwi. 2012. Sosiologi Lingkungan. Jakarta: Raja Grafindo Persada

Tim. 2015. Kamus Besar Bahasa Indonesia Pusat Bahasa (Edisi Keempat). Jakarta: PT Gramedia Pustaka Utama 